\title{
EL TRASCENDENTALISMO EN EL CINE DE DOUGLAS SIRK
}

\author{
Emeterio DÍEZ PUERTAS \\ Universidad Camilo José Cela \\ ediez@ucjc.edu
}

Resumen: El artículo estudia la presencia del trascendentalismo en las películas que Douglas Sirk rueda para los estudios Universal Internacional Pictures entre 1950 y 1959. Dicha presencia se detecta en una serie de motivos temáticos y en una carga simbólica acorde con una corriente literaria y filosófica basada en la intuición, el sentimiento y el espíritu.

Abstract: The article studies the presence of the transcendentalist in the movies that Douglas Sirk films between 1950 and 1959 for Universal International Pictures. This presence is detected in topics and symbols. Sirk unites this way to a literary and philosophical movement based on the intuition, the feeling and the spirit.

Palabras clave: Douglas Sirk. Trascendentalismo. Leitmotiv. Cine.

Key words: Douglas Sirk. Trascendentalist. Leitmotiv. Cinema. 
Hacia 1830 surge en la costa Este de Estados Unidos un movimiento literario y filosófico conocido como trascendentalismo. Se trata de una corriente intelectual que rechaza tanto el racionalismo de la Ilustración como el puritanismo conservador y el unitarismo cristiano. Sus ideas nacen bajo el influjo del romanticismo inglés y alemán, en especial, de las lecturas de Johann Wolfgang von Goethe, William Wordsworth, Samuel Taylor Coleridge y Thomas Carlyle. Los principales teóricos del movimiento se agrupan en torno a la ciudad de Concord, en Massachusetts, uno de los seis estados que forman Nueva Inglaterra. Con apenas cinco mil habitantes, esta pequeña localidad se convierte en el centro de toda una escuela de pensamiento. Allí residen, durante distintos periodos de su vida, intelectuales como el poeta y ensayista Ralph Waldo Emerson, el novelista Nathaniel Hawthorne, autor de La letra escarlata (1850), el filósofo y naturalista Henry David Thoreau, nacido en el propio Concord y discípulo de Emerson, el pedagogo y filósofo Amos Bronson Alcott y la hija de este último, Louisa May Alcott, autora de Mujercitas (1868-1869).

El movimiento se denomina trascendentalismo porque antepone lo intuitivo a la razón y la experiencia. La intuición es para ellos una fuente de verdad tan aceptable como la investigación empírica. Se puede descubrir la verdad a través del sentimiento y del espíritu. Esta forma de pensar crea una nueva forma de religiosidad, a la que luego aludiremos, y deriva en un nuevo estilo de vida, una ética basada en la exaltación de la naturaleza, la creencia en la bondad innata del ser humano, el elogio de la independencia individual frente a la imitación y el conformismo, la defensa de las minorías y un rechazo rotundo de las costumbres caducas, los convencionalismos sociales, el lujo y el éxito económico. Es más, el trascendentalismo genera una peculiar forma de entender la actividad artística. El arte, dirá Emerson, es la naturaleza pasada a través del alambique del hombre. Y ese alambique, naturalmente, es la intuición del artista: su sensibilidad para arrojar cierta luz sobre el misterio del hombre.

En estás páginas vamos a estudiar la influencia que este movimiento ha tenido en la obra del director Douglas Sirk (1900-1987), una de las figuras más representativas y notables del grupo de cineastas alemanes que llega a Estados Unidos huyendo del nazismo y un ejemplo sobresaliente de cómo el cine norteamericano refleja, en realidad, el impacto que el país provoca en los europeos. Dicha influencia apenas se ha apuntado en los ensayos sobre su obra, pese a que el propio director la ha reconocido en varias entrevistas y hasta ha incluido citas muy evidentes en sus películas. Por ejemplo, Walden de Thoreau, uno de los libros más importantes del movimiento trascenden- 
talista, aparece expresamente en la película Sólo el cielo lo sabe (All That Heaven Allows, 1955). Dice el director: «cuando leí Walden por primera vez fue como un sol que se levanta ante mi juventud: ese lenguaje extrañamente limpio. Y luego, bajo el impulso de Thoreau, leí a Emerson, un poco más tarde. No sé cómo resultarán ahora, probablemente un poco anticuados, pero entonces me causaron una fuerte impresión. Este tipo de filosofía se me quedó en la mente y tenía que encontrar finalmente una salida» (Halliday, 2002: 141) $)^{1}$.

En concreto, vamos a estudiar la presencia del trascendentalismo en las películas que Douglas Sirk rueda para los estudios Universal Internacional Pictures entre 1950 y 1959, su segundo periodo americano. Sabemos que los ejecutivos no se interfieren en su forma de filmar y hasta le permiten reescribir los guiones. Sin embargo, está obligado a rodar las producciones que el estudio le ofrece o bien debe escoger entre ciertos encargos, sometiéndose, por su puesto, a la política editorial del estudio, además de verse obligado a conseguir éxitos de taquilla. El mismo Douglas Sirk se define como un «doblegador de historias» (Halliday, 2002: 138), es decir, un cineasta que intenta llevar a su terreno una serie de guiones que, a menudo, están muy alejados de sus intereses éticos y estéticos. «Si tienes un mal guión, dice el director, puedes quemarlo o salvarlo. [...] Me daban un guión y me decían. 'Aquí tienes esta historia, tienes una estrella, trata de sacar algo de esta basura.' Pues muy bien, esto hace que tu imaginación se ponga a trabajar» (Drove, 1994: 246). En definitiva, Douglas Sirk es un trabajador bajo contrato y, por lo tanto, el sentido trascendentalista de sus películas debe ser siempre matizado y analizado en el contexto del sistema de estudios.

\section{UNIVERSAL INTERNATIONAL PICTURES}

La Universal (Gomery, 1991: 178) es una compañía cinematográfica creada en 1912 por otro emigrante alemán, Carl Laemmle, el cual había dirigido un almacén de ropa y una cadena de salas de cine antes de meterse a

${ }^{1}$ Asimismo, en la película Ángeles sin brillo (The Tarnished Angels, 1957), un personaje entrega a otro la novela Mi Antonia (1918), de la escritora Willa Sibert Cather, también afín al espíritu del trascendentalismo, pues uno de sus temas constantes es la contraposición entre la vida digna en el campo y la fatua existencia en la ciudad. Es más, durante un cierto tiempo, Douglas Sirk lleva una vida, digamos, trascendentalista, pues, poco antes de que Estados Unidos entrase en la Segunda Guerra Mundial, tuvo una granja en San Fernando Valley en la que criaba pollos y luego compró otra en Pamona County en la que cultivaba alfalfa. 
productor. Fue uno de los primeros pioneros en trasladarse a California para huir de la presión de Edison. En esta primera etapa (1912-1927), la productora se especializa en películas de bajo presupuesto, como westerns, seriales, películas de terror y melodramas.

En 1928, Laemmle regala el estudio a su hijo como obsequio de cumpleaños. Inmediatamente, la política empresarial de Carl Laemmle, Jr. se vuelve más ambiciosa. Pone en marcha su propia red de distribución y produce películas de gran presupuesto, aunque lo más recordado de su mandato (1928-1935) son las películas de terror, entre ellas, Frankenstein (1931), Drácula (Dracula, 1931) y El hombre invisible (The Invisible Man, 1933). También pertenecen a este periodo dos melodramas de John M. Stahl que luego Sirk volverá a rodar: Imitación a la vida (Imitation of Life, 1934) y Sublime decisión (Magnificient Obsesión, 1935). Sin embargo, una serie de fracasos comerciales hacen que la familia Laemmle pierda el estudio en 1936.

Su acreedor, la Standard Capital de Cheever Cowdin se hace con más del $80 \%$ de las acciones. Robert H. Cochrane se convierte en presidente de la empresa y Charles R. Rogers pasa a ser el director de producción. Pero su mandato es muy breve (1936-1937). Pronto son sustituidos por Nate J. Blumberg y Cliff Work, ambos antiguos ejecutivos de la RKO. En esta nueva etapa (1938-1945), el estudio vuelve a los westerns y a los melodramas de bajo presupuesto, siendo sus mayores éxitos los musicales de Deanna Durbin y las comedias de W. C Fields, Abbott y Costello y la Mula Francis.

En 1945, el productor británico J. Arthur Rank compra la cuarta parte de las acciones del estudio, pero un año después se las vende a la empresa International Pictures, de Leo Spitz y William Goetz. Éste último había sido vicepresidente de la Twentieth Century Pictures. Tras la fusión de ambas productoras, el estudio pasa a denominarse Universal International Pictures (UIP). Blumberg se mantiene como presidente y Goetz y Spitz asumen la dirección de la producción, marcando otro periodo de la empresa (1946-1950). En 1949, Goetz firma un acuerdo con Lew Wasserman, presidente de la compañía discográfica Music Corporation of America (MCA) y uno de los agentes de artistas más poderosos en Hollywood, con lo que la Universal ficha a estrellas de primera fila, como James Stewart, Doris Day, Lana Turner y Cary Grant.

En 1951, Decca Records, otra empresa discográfica, adquiere el 28\% de las acciones y la compañía pasa a estar controlada por dos nuevos ejecutivos: Milton Rackmil, presidente de Decca, el cual sucede a Blumberg en ju- 
lio de 1952, y Edward Muhl, ${ }^{2}$ que sucede a Leo Spitz y William Goetz como director de producción. Bajo la gestión Rackmil y Muhl (1951-1959), Douglas Sirk desarrolla la mayor parte de su trabajo, convirtiéndose en el especialista del estudio a la hora de rodar melodramas o películas para mujeres.

Bien es cierto que Sirk se relaciona directamente con los productores que dependen de Edward Muhl. Dos de ellos, tienen un papel fundamental en su filmografía y casi permiten distinguir dos grupos diferentes de películas. Albert Zugsmith, el que más libertad le da y con el que mejor trabaja, produce Escrito sobre el viento (Written on the Wind, 1956) y Ángeles sin brillo (The Tarnished Angels, 1957). Ross Hunter produce nueve de sus películas, entre ellas, Obsesión (Magnificent Obsession, 1954), Sólo el cielo lo sabe (All That Heaven Allows, 1955) e Imitación a la vida (Imitation of Life, 1959). Esta última recauda 13 millones de dólares y se convierte en uno de los tres grandes éxitos de taquilla del estudio en aquel año ${ }^{3}$. Pero después de veinte películas con la Universal y estando en la cima del éxito, Douglas Sirk se retira un tiempo por problemas de salud. Cuando tiene oportunidad de volver, desiste porque considera que su tiempo ha pasado. El fin de su carrera coincide con el fin de la gestión de Rackmil y Muhl al frente del estudio 4 .

2 Edward Muhl había ingresado en la Universal en los años veinte y permanece más de cuarenta y cinco años en el estudio, veinte de ellos como jefe de producción. Gran defensor del cine en Tecnicolor, había comenzado trabajando en el departamento de contabilidad y pronto se gana la confianza de Carl Laemmle y también de los sucesivos presidentes del estudio.

${ }^{3}$ Los otros dos éxitos de taquilla son Operación Pacífico (Operation Petticoat, 1959), que recauda 18,6 millones de dólares y Confidencias a medianoche (Pillow Talk, 1959), con 15 millones.

${ }^{4}$ La compañía, en efecto, entra en crisis por la presión de la televisión (varias veces citada de forma despectiva en las películas de Sirk). En 1959, la MCA se hace con el control del estudio. Rackmil y Muhl son sustituidos en sus puestos por Lew Wasserman y Jules Stein. Este último había fundado MCA en 1924 en Chicago, mientras Lew Wasserman se había unido a la empresa en 1936, convirtiéndose en presidente en 1946, además de crear una de las agencias de artistas más importantes de Estados Unidos. Se ha dicho que MCA es la compañía que la mafia utilizó para infiltrarse en Hollywood. Lo cierto es que bajo la dirección de Lew Wasserman, MCA/Universal extiende sus negocios a la televisión y el mundo del ocio, convirtiéndose en una de las empresas cinematográficas más importantes del mundo.En 1990, Lew Wasserman vende MCA/Universal a la empresa japonesa Matsushita Electric, quien 5 años después debe abandonarla por no adaptarse al mercado americano. En 1995 el control pasa a una compañía canadiense distribuidora de licores Seagram, que también compra Polygram y otras empresas del sector. En el año 2000, los malos resultados ponen de nuevo en venta el estudio, que es adquirido por Vivendi. Pero agobiada por las deudas, Vivendi vende parte de la empresa a la General Electric, poseedora de la cadena de televisión NBC. Surge así una nueva compañía NBC Universal. En el año 2005, la General Electric poseía el $80 \%$ de las acciones y Vivendi el $20 \%$ restante. 


\section{UNA MORAL TRASCENDENTALISTA}

Las películas de Sirk para la Universal muestran cómo la mayoría de los norteamericanos llevan lo que Thoreau llamaba una vida de tranquila desesperación. Para salir de ella, el trascendentalismo y el cine de Sirk proponen una moral basada en cinco postulados: búsqueda de un ideal superior, retorno a la naturaleza, defensa de la autonomía del individuo, rechazo de los convencionalismos sociales, crítica del capitalismo y apoyo a las minorías.

Por lo que se refiere al primer postulado, el trascendentalismo defiende la creencia de que, por encima de la realidad, existe una existencia superior (la del espíritu), a la cual se llega mediante la experiencia de los sentidos. Lo que Emerson entiende por religiosidad trascendente es la capacidad innata de cada individuo para llegar a la unión con un alma superior (que podemos llamar Dios) sin necesidad de milagros, jerarquías religiosas ni otro tipo de mediaciones. Sobran las iglesias, los ritos, los curas, las imágenes de los santos... El hombre trascendentalista entiende que lo divino impregna todos los elementos que pueblan la tierra. Dios está en la belleza del mundo circundante. A través de lo natural (la naturaleza y el hombre) se llega a la sobrenatural (Dios) $)^{5}$.

Pues bien, los ejecutivos de la Universal, siguiendo la moda imperante, proponen a Sirk una serie de películas religiosas con un material literario previo muy conservador. ${ }^{6}$ De hecho, dada la época de estos filmes, se trata de

\footnotetext{
${ }^{5}$ El trascendentalismo tiene cierta relación con el gnosticismo, movimiento religioso esotérico que surge en los primeros años del cristianismo. Los gnósticos se oponen a las reglas socialmente establecidas, a los mandamientos, a la jerarquía eclesiástica. Denuncian al hombre obsesionado por la materia y por acumular cada vez más cosas. Dado que Dios está dentro de nosotros, propugnan una vida basada en la búsqueda individual, en un viaje hacia el conocimiento propio, en la contemplación sosegada del yo, una vida dedica al descubrir el misterio de quiénes somos. Sabemos mucho del mundo y muy poco de nosotros mismos. Buscar la sabiduría o gnosis (el conocimiento revelado) dentro de cada uno es lo que da sentido a la vida, porque si encontramos el camino hacia nosotros mismos, encontraremos el camino hacia Dios. Para encontrar a Dios, el hombre tiene que encontrar al Cristo que está en su interior. En definitiva, el gnosticismo propone una búsqueda individual de la Salvación. Jesús nunca dejó instrucciones para la creación de una Iglesia.

${ }^{6}$ Dentro de la cinematografía estadounidense el cine religioso o de temática religiosa es más frecuente de lo que se piensa. Por ejemplo, el grupo de presión católico en Estados Unidos, además de tener una política muy activa en materia de censura, financia o promueve numerosas producciones. En los años cuarenta fueron grandes éxitos de taquilla películas como La canción de Bernadette (1943), Siguiendo mi camino (Going My Way, 1944) y Las campanas de Santa María (The Bells of St. Marys, 1945). En los años cincuenta, además de las películas con monja, como Tempestad en la cumbre (Thunder in the Hill, 1951), del propio Sirk, e Historia de una monja (The Nuns Story, 1959), el ciclo más importante procede del cine épico: Sansón y Dalila (Samson and Delilah, 1949) y Los diez mandamientos (The Ten Commandments, 1956) de la Paramount, Quo Vadis? (1951) y Ben-Hur (1959) de la MGM, La túnica sagra-
} 
parábolas sobre la Guerra Fría, como Atila, rey de los hunos (Sign of the Pagan, 1954), donde los hunos son los comunistas y su estandarte guerrero, la hoz y el martillo del siglo V. Incluso, Sirk se ve obligado a rodar una película que trata directamente del conflicto entre la URSS y Estados Unidos. Me refiero a Himno de batalla (Battle Hyms, 1957), ambientada en la Guerra de Corea. Sirk, no obstante, intenta imbuir a este material de cierto espíritu trascendentalista, en el sentido de que rechaza el materialismo (el comunismo) e intenta rebajar el puritanismo ultraconservador, cuya fe en Dios se basa en manifestaciones religiosas extremas y pomposas. Así mismo, afronta el material con curiosidad y aplicación, pues, como buen trascendentalista, entiende que la religión es una parte fundamental de la vida del hombre:

Veo la religión como una parte muy importante de la sociedad burguesa. Es un pilar de esta sociedad, aunque sea un pilar roto. El mármol muestra cierto deterioro. Si quieres hacer películas sobre esta sociedad, creo que es un ingrediente de un pasado encanto; encanto en el sentido original de la palabra: hechizo.

Siempre me ha interesado la religión, aunque no haya estado en la iglesia desde hace décadas. Es una de mis preocupaciones constantes. Incluso no creer en Dios es un acto religiosos en cierto modo. [...] Creo que todo trata de la religión: de las cosas desconocidas en el hombre (Halliday, 2002: 122).

Un ejemplo de trascendentalismo religioso podía haber sido Tempestad en la cumbre (Thunder in the Hill, 1951), primera película de serie A que Sirk rueda para la Universal. Sin embargo, sólo lo es en ciertos aspectos. El director más bien reniega de ella. Basada en una obra teatral de Charlotte Hastings, la película relata cómo una monja consigue salvar a una mujer condenada a muerte hallando al verdadero culpable. La monja se llama Sor Buenaventura (Claudette Colbert) y como su nombre indica tiene un don para adivinar el destino de las personas. Ahora bien, no estamos ni ante un milagro ni ante una especie de gitana. Sus dotes residen en eso que los trascendentalistas llaman instinto. Los personajes que critican a la monja le reprochan que siempre se crea en poder de «la razón», pero terminan reconociendo que, en efecto, acierta en sus vaticinios, si bien ella nunca alardea de ello. Así, después de salvar a la mujer condenada a la horca, Sor Buenaventura dice que las monjas del hospital han sido elegidas por Dios para proteger

da (The Robe, 1953), de la 20th Century Fox, Rey de reyes (King of Kings, 1960) y La caída del Imperio Romano (The Fall of the Roman Empire, 1963) de Samuel Bronston Productions o Atila, rey de los hunos (Sign of the Pagan, 1954), de la Universal, también dirigida por Sirk. 
a un inocente, repartiendo el mérito entre todas las hermanas. Pero la madre superiora, que se había opuesto a su «corazonada», le contesta en el último diálogo de la película con una frase que es un elogio de su actitud, frase que contienen la moraleja de la película: «Tener razón es un don del cielo que se mal gasta sino se utiliza con humildad.» El director valora así este filme: «Tanto el autor del argumento como el guionista y el productor querían una película religiosa con mensaje y todo eso. Y no puede ser. La religión es algo demasiado... digamos mágico, y debe ser misteriosa, debe permanecer como algo extraño, ajeno a nosotros, algo ininteligible para los espectadores. Y creo que la película llego a ser demasiado explícita, se volvió demasiado clara» (Drove, 1994: 256).

Precisamente, la magia, el misterio y la intangibilidad están presentes, a través del punto de vista de Atila, en su siguiente película religiosa: Atila, rey de los hunos (Sign of the Pagan, 1954). La Universal quería hacer una película con el actor Jeff Chandler que tratara de religión, sin duda para unirse a la moda del cine épico bíblico. Sin embargo, el verdadero protagonista del filme es Atila (Jack Palance). Su deslumbramiento ante «la naturaleza» del Dios cristiano es, en realidad, la conversión de un trascendentalista. Por otra parte, el filme plantea la guerra entre bárbaros y romanos, entre paganos y cristianos, mediante un régimen de símbolos que dotan a la película de ese espíritu interno e insondable que Sirk reivindica para el fenómeno religioso. Volveremos después sobre esto.

Finalmente, Himno de batalla (Battle Hyms, 1957) es un proyecto que le llega a Sirk directamente de Edward Muhl. Como dice el propio director, el filme mezcla ética, religión, mística, magia y creencia (Holliday, 2002: 150). Cuenta la historia real del piloto de guerra Dean Hess (Rock Hudson). Tras matar a docenas de niños al bombardear en Alemania un orfanato, Dean se hace predicador. Sin embargo, no siente que de esta forma expíe su culpa. Más bien piensa que estafa a sus fieles. Decide entonces volver al ejército y combate en la guerra de Corea. Pero, después de bombardear las líneas enemigas, se dedica a salvar huérfanos. Utiliza como orfanato un templo budista, donde se encuentra con una especie de anciano sabio (el pensamiento oriental influye también en el trascendentalismo). Al principio, Dean Hess no sabe muy bien cómo compaginar guerra y caridad. Es uno de esos personajes escindidos e inseguros de tanto gustan a Sirk, aunque parece ser que en el personaje real carecía tal escisión. Entendía perfectamente la existencia de un Dios vengador, de un Dios, al mismo tiempo, salvador y ejecutor. Al final, la tarea de proteger a los niños y el auxilio religioso que presta a su mejor amigo en el momento de su muerte, consiguen que el protagonista comprenda un 
mensaje netamente trascendentalista: «El amor y la protección a los demás nunca serán destruidos.»

Naturalmente, Sirk no solo desliza su concepción trascendente de la vida en el cine religioso y antimarxista que le encarga el estudio. Más bien son otro tipo de películas con una carga mística muy evidente, como Obsesión (Magnificient Obsesión, 1954) y Tiempo de amar, tiempo de morir (A Time to Love and a Time to Die, 1957), las que mejor manifiestan su «espiritualidad». En Tiempo de amar, tiempo de morir encontramos el siguiente diálogo:

Ernst Graeber-_ ¿Dígame, profesor, existe todavía algo en lo que se pueda creer?

Profesor Pohlmann.-Sí, existe.

Ernst Graeber- ¿Qué es?

Profesor Pohlmann.-Dios.

Ernst Graeber-_ ¿Sigue usted creyendo en él?

Profesor Pohlmann.-Más que nunca.

Ernst Graeber- - ¿Sin el menor asomo de duda?

Profesor Pohlmann.-Claro que las tengo. Si no hubiera dudas, no habría necesidad de la fe.

Ernst Graeber- ¿Cómo se puede seguir creyendo en Dios con lo que está ocurriendo aquí?

Profesor Pohlmann.-Dios no es responsable de lo que nos pasa. Y sí nosotros ante el de nuestras torpes y mañas acciones.

Ernst Graeber-_Si eso es cierto, ¿qué responsabilidad tengo yo, profesor? Quizás nuestro pueblo está sufriendo este castigo por haberse apartado de todas sus creencias. Las que practicaban nuestros padres y que todos hemos olvidado. He de tomar una decisión, profesor. Necesito saberlo.

Profesor Pohlmann.- Nadie puede tomar esa decisión por usted. Ni si quiera su maestro. Cada hombre tiene que decidirlo por sí mismo. Pero primero hay que enfrentarse con la verdad, por horrible que sea. Se pierde la guerra, Ernest. Y lo más terrible es que la perderemos antes de que el país haya encontrado su alma.

En segundo lugar, y tal y como es propio del trascendentalismo, la naturaleza y el campo constituyen en las películas de Sirk los ámbitos donde el hombre encuentra el gozo, la libertad, el espíritu y la energía. Su cine plantea una actualización del motivo del beatus ille: la huida del mundo y de sus afa- 
nes y el refugio en la paz del campo, donde el personaje se entrega a la contemplación y el conocimiento. La naturaleza es símbolo de lo verdadero y de lo genuino, del espiritualismo y la libertad, mientras la civilización y la ciudad representan todo lo contrario: el materialismo y la alienación. Es más, todo su cine, como luego veremos, se sirve de la función simbólica de la naturaleza: el lago, el árbol, las flores, el ciervo, la paloma, las piedras... La película que mejor expresa esta idea es Solo el cielo lo sabe. Su protagonista masculino, Ronald Kirby (Rock Hudson), es una especie de Thoreau del siglo Xx: agrimensor, jardinero, granjero, carpintero, estoico, la sinceridad en persona, ajeno a toda hipocresía... Incluso, la película se rodó en la ciudad de Concord, centro del trascendentalismo. El filme, en concreto, cuenta la historia de una viuda, Cary Scoot (Jane Wyman), que se enamora de su jardinero, Ronald Kirby, quince años más joven. La relación es imposible por la oposición de los hijos de Cary, los comentarios de su círculo social y el miedo de la propia protagonista a dejar su vida burguesa. Al final, sin embargo, Cary rompe con todo y se va a vivir con Ron a su granja ${ }^{7}$.

El tercer postulado trascendentalista, creer en uno mismo y despreciar la imitación y el conformismo, es una idea que la mayoría de los personajes de Sirk ignoran. Sólo unos pocos, como Ronald Kirby (Solo el cielo lo sabe) y Micht Wayne (Escrito sobre el viento), aprenden a confiar en sí mismos, se guían por su instinto, actúan como individuos completos y autosuficientes. ${ }^{8}$ La mayoría de los personajes de Sirk, en cambio, permanecen vacilantes y confusos. Son ciegos (de forma literal o metafórica) a la verdad trascendentalista. Me refiero a Helen (Obsesión), a Cary Scoot (Solo el cielo lo sabe), a Clifford Croves (Siempre hay un mañana), a Kyle Hadley (Escrito sobre el viento), a Lora Meredith (Imitación a la vida) o al propio Atila (Atila, rey de los hunos), que el director tacha de variante violenta del mismo fenómeno. «La inseguridad y la vaguedad de los objetivos del hombre, dice Sirk, están en el centro de mis películas, por ocultas que puedan hallarse esas características» (Holliday, 2002: 63).

Por lo que se refiere al rechazo de las costumbres y de los convencionalismos sociales, el cine de Sirk realiza una profunda crítica del «american wife of live». La Norteamérica segura, confortable y libre, esconde, en rea-

\footnotetext{
7 Igualmente, en Ángeles sin brillo, Laverne Shuman (Dorothy Malone) deja la ciudad y regresa al campo, donde espera dar a su hijo una verdadera educación.

${ }^{8}$ Ronald Kirby es presentado con estas palabras: «Su seguridad viene de lo más íntimo de su ser y ni nada ni nadie podrá jamás arrancárselo. Ronald desdeña absolutamente las cosas banales y sin importancia» (minuto 30).
} 
lidad, una sociedad llena de miedos, insatisfacción y prejuicios. En Siempre hay un mañana (There`s Always Tomorrow, 1955), remake de otra película de la Universal rodada en 1934, el protagonista Clifford Croves (Fred MacMurray) lleva una vida muy feliz gracias a su familia y a su fábrica de juguetes. Pero un día aparece un antiguo amor, Norma Miller (Barbara Stanwyck), y comprende que, en realidad, lleva una existencia vacía. Clifford quiere huir con Norma, pero ésta no desea destrozar su núcleo familiar y lo abandona. Al final, vemos que los hijos contemplan a sus padres cogidos del brazo tras una especie de barrotes, lo cual da entender que Clifford se entierra en vida, tal y como, en el fondo, también querían los hijos de Cary en Solo el cielo lo sabe, película con la que guarda muchos parecidos, solo que en aquella la protagonista rompe con la sociedad y aquí se acatan las convenciones.

Otro tema trascendentalista es la denuncia del capitalismo salvaje, del lujo y del éxito económico. Thoreau decía que los negocios son lo más parecido al crimen o tienen consecuencias casi similares. Convierten el mundo en un lugar de ajetreo, explotación y pillaje. Nada peor para el hombre que someter su vida a la consecución de dinero. Es la actitud propia de un tonto. La riqueza de un hombre, dirá Thoreau, se mide por la cantidad de cosas de las que es capaz de privarse, pues solo entonces puede ser un individuo realmente autónomo. La mayor parte de los lujos y comodidades de la vida son impedimentos para la elevación de la humanidad. La película de Sirk que mejor expresa estas ideas es Escrito sobre el viento. En ella, Mitch Wayne (Rock Hudson) conoce y se enamora de Lucy (Lauren Bacall). Sin embargo, ésta se casa con su amigo y medio hermano Kyle Hadley (Robert Snack), hijo del magnate del petróleo Jasper Hadley (Robert Keith). A pesar de todos sus millones, Jasper se considera un fracasado en lo que se refiere a su familia y sus hijos. En especial, está decepcionado porque su heredero no está hecho, como él desearía, de la pasta de Mitch. Tras la boda, Kyle abandona el alcohol y deja de ser un inútil, pero todo se viene abajo cuando un médico le comunica que es estéril. Sus nuevas barrabasadas, y las de su hermana Marylee Hadley (Dorothy Malone), le llevan al él mismo y a su padre a la muerte.

Finalmente, el tema de las minorías tiene una gran importancia para los trascendentalistas, ya que defender otras formas de vida y otras rasgos raciales supone ratificar los postulados anteriores, es decir, que cada hombre tienen derecho a ser él mismo, sin que convencionalismo sociales o maximalismos económicos discriminen a nadie en razón de raza y clase. La historia de Annie (Juanita Moore) y su hija Sarah Jane (Susan Kohner) en Imi- 
tación a la vida es el mejor paradigma de este principio. Sarah, dado el color casi blanco de su piel, se niega a reconocer que es de raza negra. Sólo tras la muerte de su madre, admite su verdadera identidad. Es más, al contraponer el despropósito de Sarah Jane (una negra que quiere ser blanca) con la ambición de Lora Meredith (una madre que quiere ser una gran estrella), Douglas Sirk deja muy patente el significado trascendentalista sobre el que insiste una y otra vez en sus películas: solo se puede ser lo que uno es, tanto a nivel biológico (la naturaleza) como cultural (la personalidad).

\section{UNA ESTÉTICA TRASCENDENTALISTA}

El vínculo de Sirk con el movimiento surgido en Concord se establece también en el plano formal. Su concepción del arte está inspirada en postulados propios del romanticismo, pues el movimiento trascendentalista es, digamos, una rama de aquel. Aunque, quizás, Sirk haya conocido primero el romanticismo europeo (su montaje de Los bandidos de Schiller es uno de sus grandes éxitos como director teatral) y luego haya descubierto el trascendentalismo americano. Lo cierto que su deslumbramiento por la naturaleza y su continua reflexión sobre el yo mediante unos personajes sonámbulos, casi trágicos, son temas netamente románticos, como es puro romanticismo su estilo artificioso, simbólico, estilizado y sofisticado. El propio Sirk, para definir el estilo de sus últimas películas, emplea tres expresiones que aluden a tres corrientes artísticas dentro de lo que Nietzsche llama el arte dionisiaco: manierismo, barroco y formalismo. Se salta el romanticismo, pero también podría haber empleado esta expresión, ya que todas esas corrientes plantean un alejamiento de lo apolíneo: el clasicismo, el realismo y el naturalismo.

En concreto, aquí vamos ejemplificar la forma trascendentalista de los filmes de Sirk haciendo hincapié en la fuerte carga simbólica, casi críptica, presente en sus películas. Sirk escoge objetos tópicos y cotidianos, casi vulgares, los estiliza con el tratamiento dramático y plástico (la iluminación, el color, la composición...) y construye con ellos artefactos que contienen complejas metáforas (González Requena, 1986: 192). Hay en su cine cierto esoterismo, esto es, una invitación a ir más allá de lo externo, una incitación a buscar lo que permanece oculto. Incluso en muchas de sus películas, los títulos de crédito iniciales y finales consisten en imágenes simbólicas: los diamantes en Imitación a la vida; el árbol en Tiempo de amar y tiempo de morir; la vidriera y el casco (créditos iniciales) y los dos pinos (créditos finales) en Himno de Batalla; o bien la torre (créditos iniciales) y el ciervo (créditos fi- 
nales) en Sólo el cielo lo sabe. Se trata de un simbolismo donde el simbolizante es, como ya se ha dicho, un elemento tomado casi siempre de la naturaleza (la paloma, el lago, las flores, los árboles...), mientras que lo simbolizado expresa de algún modo esa búsqueda de uno mismo en la que se embarcan los trascendentalistas. «La naturaleza, dirá Emerson, es el símbolo del espíritu».

Tomemos el caso de Obsesión ${ }^{9}$. La película se ha interpretado como una manifestación del complejo de Edipo (González Requena, 1986: 98-99) ${ }^{10}$, un sentido estructural que, con toda seguridad, no había previsto el autor de la novela en que está basada la película, nada menos que el clérigo luterano Lloyd Cassell Douglas ${ }^{11}$. Lo cierto es que el sentido autorial del filme vuelve a ser claramente trascendentalista, pues viene a decir que la filantropía, esto es, dedicar nuestra vida a los demás, es una magnifica obsesión.

Este tema queda expresado simbólicamente en la escena en la que Edward Randolph (Otto Kruger) explica a Bob Merrick la metáfora de la lámpara (hacia el minuto 33). Randolph dice que una lámpara apagada está completa en todas sus partes, pero no cumple su función. Para que dé luz hay que abrir una llave. Sólo entonces llega el fluido producido en la central eléctrica. Con los hombres sucede algo similar. Están apagados, no son verdaderos hombres hasta que se abre la llave que les pone en contacto con Dios, o si se quiere, con una meta superior, espiritual. Y esa llave no es otra que ponerse «al servicio de los demás. Buscar a quien necesite ayuda y ayudarle, pero siempre en secreto, sin proclamarlo nunca y sin pedir una recompensa.» El anonimato, sigue la metáfora, es necesario como es necesario que el cable eléctrico vaya aislado y oculto para que no pierda fuerza la corriente. Hay que aislar la fuerza (lo superior) de la personalidad (el individuo). Esto mismo es lo que hizo Jesucristo. Y minutos más tarde Randolph dice: «Dedicar nuestra vida a los demás, sujetarla al temperamento de cualquier otra persona no crea que es empresa fácil [...] En cuanto la emprenda, se verá atado. Y

\footnotetext{
${ }^{9}$ La película narra la historia de un joven calavera llamado Bob Merrick (Rock Hudson). Éste sufre un accidente y tiene que ser tratado con un pulmón artificial justo en el momento en que su dueño, el doctor Phillips, también lo necesita, falleciendo por su culpa. El joven trata de reparar lo sucedido prestando todo tipo de cuidados a su viuda, la señora Helen Phillips (Jane Wayman), de la que se termina enamorando. Pero de nuevo una imprudencia suya provoca un accidente y la mujer queda ciega. Convertido a la filosofía del trascendentalismo, Merrick se transforma en un hombre nuevo. Hellen, sin embargo, no quiere su compasión y huye de su lado. Años después, Merrick opera a su amada y ésta recobrar la vista, iniciándose por fin una relación entre ambos.

${ }^{10} \mathrm{El}$ joven Merrick mata al doctor Phillips/padre para quedarse con su esposa/madre.

${ }^{11}$ Un año antes se había llevado al cine su novela más popular: La túnica sagrada (The Robe, 1953).
} 
nunca podrá zafarse. Descubrirá en ello una fuerza impulsora que le obsesionará. Créame, será una magnífica obsesión» (minuto 49) ${ }^{12}$. En definitiva, en contraposición con la ceguera (real o metafórica) que sufren los personajes, Sirk utiliza un simbolizante, la lámpara (y su luz), que los trascendentalistas vinculan con el espíritu y lo superior.

En Atila, rey de los hunos, el combate entre paganos y cristianos también tiene lugar en el plano simbólico. El cristianismo está representado por una serie de imágenes relacionadas con la cruz. El paganismo, por su parte, se plasma mediante la imagen de un signum o enseña del ejército de Atila. Su simbolismo está marcado, como es propio en este tipo de estandartes, por los objetos que lleva y sus atributos. En este caso, el signum de los hunos consiste en la cabeza de un toro (formada por unos cuernos, un triángulo invertido y una calavera de este animal), además de la calavera de dos hombres y varios penachos de pelo. El toro simboliza al dios pagano Thor y lo demás alude a las víctimas de este dios guerrero. Este leitmotiv es la primera imagen de la película y sobre ella aparece el título del filme, que hace muy explícito su significado: Sign of the Pagan.

Durante la primera parte de la película, el símbolo que domina es el pagano. Pero hacia la mitad aparece por primera vez el símbolo de la cruz, si bien de una forma muy singular. Un rayo destruye un árbol matando, al mismo tiempo, a uno de los astrólogos de Atila, aquel que ha predicho la caída de Roma. El árbol queda tendido en el suelo en forma de «Y», que es otra forma de reproducir la cruz, ya que este símbolo deriva del árbol de la vida del paraíso y, en la Edad Media, se representaba, precisamente, como un árbol en forma de «Y». Desde este momento, Atila comienza a temer al Dios de los cristianos y sospecha que puede hacerse realidad una profecía: que morirá envuelto en un charco de sangre y ante la sombra de una cruz. Esto es precisamente lo sucede en el clímax del filme, mientras el fuego destruye el estandarte de los hunos. Atila, en efecto, muere con un puñal cuya empuñadura tiene la forma de la cruz mientras dice «vuestro Dios me ha vencido».

En Sólo el cielo lo sabe el estilo manierista de Sirk se traduce en toda una serie de símbolos trascendentalistas: la torre, el reloj, el árbol llamado lluvia

\footnotetext{
12 Parte de este diálogo vuelve a oírse con la voz superpuesta de Randolph cuando Merrick descubre que su amada le ha abandonado: «En cuanto inicie la empresa no podrá zafarse. Descubrirá en ello una fuerza impulsora que le obsesionará. Créame, será una magnífica obsesión.» (minuto 86). Y las últimas palabras de la película son de nuevo este parlamento en voz superpuesta acompañado de una musical coral mientras Randolph deja solo a los amantes: «Una vez emprendido el camino quedará atado a él. Será algo que le obsesionará. Será una magnífica obsesión» (minuto 103).
} 
dorada, la rama de este árbol, el árbol de navidad, la paloma (otoño), el ciervo (invierno), el vestido rojo, el fuego en el hogar, la copa (que representa al señor Scoot), la casa como cárcel, el molino como vuelta a la naturaleza y, por supuesto, los espejos. Dejando de lado estos últimos, los que mejor expresan la orientación de la película («El hombre debe ser sincero con uno mismo y tomar sus propias decisiones sin ningún miedo» ${ }^{13}$ ) son la torre, los árboles, la paloma y el ciervo. La torre de la iglesia aparece tres veces, actuando, además, como telón teatral que divide el film en tres partes o actos. La torre (símbolo de múltiples significados: virilidad, impotencia, individualización...) viene a ser en el filme un signo de transformación, en el sentido de que elevarse por encima de la tierra, de la vida normal o social, es acercarse al cielo y, por lo tanto, a una vida más espiritual. El árbol simboliza la naturaleza humana y conecta los tres mundos: el infierno (raíces), la tierra (tronco) y el cielo (ramas). La paloma es símbolo de espíritu, de una vida alejada del materialismo, como piden los trascendentalistas. Cuando llega el invierno, este animal es sustituido por el ciervo, el cual encierra al mismo tiempo el simbolismo de la torre, del árbol y de la paloma, es decir: 1) como la torre, es un símbolo de elevación; 2) se relaciona con el árbol de la vida por su cornamenta; y 3) al igual que la paloma, es un mensajero de los dioses, además de simbolizar la vida en soledad y en la pureza, que es la que escogen Roland y Cary, como indica la última imagen del film.

En Siempre hay un mañana, vuelven a repetirse los motivos del espejo, el fuego en el hogar, la casa como cárcel o la dicotomía entre la ciudad (Los Ángeles) y la naturaleza (Palm Valey). Pero los objetos más singulares son el robot Rex y el organillo donde se oye la canción Blue Moon of Kentucky. El primero representa al hombre alienado. Dice el protagonista en un momento del filme: «Estoy cansado de no pintar nada, de que nadie me tome en serio. Me he convertido en uno de mis juguetes: Crifford Groves, el robot parlante. Dame cuerda por la mañana y hablo y muevo, trabajo todo el día. Dame cuerda otra vez y vuelvo a casa, ceno y me acuesto. Dame cuerda por la mañana y voy a la oficina y trabajo como un negro y pago las facturas... Estoy harto [de que mi vida] sea lo mismo día tras día» (minuto 47).

${ }^{13}$ Minuto 42. Incluso, como ya hemos dicho, las teorías trascendentalistas están presentes de forma directa, pues aparece el ensayo de Thoreau Walden. Este libro, se dice en uno de los parlamentos, es la Biblia del expublicista, el cual ha dejado la ciudad y una vida de lujo que no podía soportar. Ronald, por su parte, practica esa Biblia sin saberlo, en especial, la máxima «Sé sincero contigo mismo». Al final de la película Cary se pregunta por qué ha tardado tanto en darse cuenta de este principio trascendentalista y la mujer del publicista le dice: «Sencillamente porque nosotros tardamos mucho tiempo para hallar la explicación adecuada. No se consigue en una noche.» Cary responde: «Me siento tan culpable. Estaba tan asustada que hice caso a los demás. Permití que decidiesen por mí» (minuto 80). 
El organillo, o mejor dicho, su música evocadora del pasado, representa todo lo contrario del robot: la posibilidad de ser un hombre libre y nuevo. La canción Blue Moon aparece en todos los encuentros entre Clifford Croves y Norma Miller. Con ésta, el protagonista rompe su vida monótona e insulsa. «Es curioso, dice el protagonista, lo fácil que es para el hombre caer en la rutina. Una vez que está metido en ella no se atreve a hacer lo que hacía antes y no siente el entusiasmo que antes sentía. En el fondo, la vida le da un poco de miedo» (minuto 26). Asimismo, juguete y música coinciden en unas de las escenas clave del filme, cuando Norma rompe con Clifford (minuto 74) y éste se queda solo con el robot, que se pone a andar y se precipita al vacío mientras la música de Blue Monn se transforma en un desgarro.

El simbolismo de Escrito sobre el viento está todo él resumido en la escena de los títulos de crédito iniciales. En esas imágenes vemos las torres de petróleo, el logotipo con la letra $\mathrm{H}$, el viento, la escalera y la pistola. (Incluso podríamos incluir el coche deportivo como símbolo de irresponsabilidad y vida disoluta.) Luego aparecen otras imágenes simbólicas reiteradas en el cine de Sirk: los espejos, el vestido rojo, la vivienda como prisión o bien el lago y la naturaleza como signos de vida pura. Pero aquí nos interesa los primeros porque son los que resumen el sentido particular de este filme: el fracaso y la frustración que hay detrás del aparente éxito económico.

Ya hemos dicho que la torre, presente también en Solo el cielo lo sabe, tiene numerosas interpretaciones. La mayoría de los estudiosos sobre Escrito en el viento relacionan las torres de petróleo con el falo o con su carencia

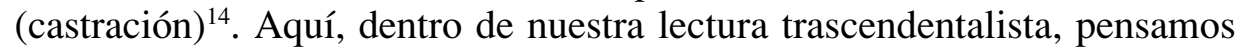
que tiene otro significado: simboliza el éxito en la vida (tal y como se entiende en una sociedad materialista, es decir, como posesión del oro negro), pero también la altanería, el egocentrismo y el exceso de orgullo que el éxito social implica, así como la vida alejada de la realidad y la vida condenada a la soledad que trae ese carácter (ese situarse por encima de). Esta segunda interpretación viene a coincidir con el simbolismo de la letra «H», logotipo de los Hadley impreso por todas partes: coches, edificios, depósitos de petróleo... La letra $\mathrm{H}$, en efecto, es una letra cerebral que atrae el éxito y el di-

\footnotetext{
${ }^{14}$ Cuando Marylee Hadley abraza la torre al final del filme, es cuando ésta cobra su pleno sentido sexual. La torre no es sólo el pene sustitutivo de Mitch, sino que representa la superación del complejo de castración, pues tanto ella como su hermano temían ser destruidos por el padre o, más bien, sufrían un sentimiento de culpa porque pese a su comportamiento disoluto, manifestación de su odio hacia él, el padre los quería. Por otro lado, la torre es un acto de sublimación de su instinto sexual. Tal y como había hecho antes el padre, Marylee, ahora con unas ropas recatadas, sustituye el deseo sexual por los negocios.
} 
nero, pero que también te quita todo lo que te da, tal y como le sucede al magnate. La escalera, por su parte, simboliza, si se sube, la posibilidad de ascender en la escala de valores, de alcanzar una vida más espiritual. En cambio, si se baja, como hace Marylee en la escena de los títulos de créditos, y como le ocurrirá con su padre cuando sufra el ataque al corazón, representa la posibilidad de caer en peligros y de degradarse. En cuanto al violento y fuerte viento, es un símbolo del caos y de la destrucción que provocan las decisiones personales equivocadas, en este caso, la vida disoluta de los hijos del magnate y su propio fracaso como padre. Es una amenaza que se cierne sobre los planes y el futuro de la familia. Finalmente, la pistola de los Hadley expresa su falta seguridad en sí mismos, la fragilidad de su imperio y también su visión de la vida como una lucha sin cuartel, donde nadie es de fiar y la agresividad es la forma de resolver los problemas sociales y personales, incluido el suicidio. En definitiva, los Hadley son otro ejemplo de vida equivocada. Todos sus símbolos (la torre, la $\mathrm{H}$, la escalera, el viento, la pistola) lo $\operatorname{connotan}^{15}$.

Por otra parte, además del simbolismo específico de cada filme, existen una serie de imágenes que aparecen en todas o casi todas las películas de Sirk. Hemos hablado, por ejemplo, de la imagen de la casa como una cárcel, incluso como una tumba, muy evidente en Obsesión, Sólo el cielo lo sabe, Siempre hay un mañana y Escrito en el viento (el último plano de esta película es la verja de la mansión cerrándose como la puerta de una prisión). De hecho, Sirk ha dicho que si en sus películas hay tantas flores en las casas es porque también las hay en las tumbas.

Pero, quizás, los dos símbolos más importantes del cine de Sirk, en relación con el trascendentalismo, sean el círculo y el espejo. El círculo se relaciona con el arquetipo del mándala y, por lo tanto, con la búsqueda del símismo o contenido profundo (inconsciente) de la personalidad, que es el tema último del trascendentalismo. Aunque el cine de Sirk presenta objetos

\footnotetext{
${ }^{15}$ Otro caso, en el que no nos detendremos es Himno de batalla. La película expresa su tema con dos símbolos presentes en los créditos iniciales: una vidriera (la Iglesia) y un casco de aviador (el Ejército), acompañados de un himno religioso que parece una marcha militar. En todo ello está presente la mezcla de religión y guerra que caracteriza al protagonista, al mismo tiempo predicador y soldado. El protagonista, en efecto, al auxiliar a su amigo en su muerte, comprende que ha «sido el instrumento que hubiera deseado y necesitado ser. Quizás gracias a la agonía de la guerra he podido, al fin, realizar lo que antes no fui capaz de hacer. He tenido que prescindir de mí mismo para encontrarme conmigo mismo» (minuto 81). La película se cierra con otro himno religioso y un plano de dos pinos. El pino es, por un lado, símbolo de la eternidad, «pues al conservar su verdor todo el año parece vivir eternamente» (minuto 45). Pero también representa el amor que la maestra Anna Kashfi (En Soon Yang) siente por el coronel Dean Hess, pese a «que no pudieron unir su vidas en este mundo» (minuto 57 y 109).
} 
circulares, como la noria y otras atracciones de feria en los Ángeles sin brillo, el símbolo se encuentra, sobre todo, en la estructura circular de muchas de sus películas, en especial, Siempre hay un mañana, Escrito en el viento y Tiempo de amar, tiempo de morir. Dice el director: «Me interesa la circularidad, el círculo: la gente que vuelve al lugar de que partió. Por eso encontrarás rondós trágicos en muchas de mis películas, gente que se mueve en círculos. Esto es lo que hace la mayoría de mis personajes.» Y en otra entrevista dice: [La estructura rondó] empieza con una situación que no parece feliz del todo, la película sigue y acaba en un final feliz. Parece un final feliz... pero básicamente resulta ser la misma situación del principio. [...] Esta estructura de rondó es, de algún modo, un estilo pesimista. No puedes escapar a la rueda del destino» (Drove, 1994: 278). El círculo es el símbolo más representativo de lo que Gilber Durán llama el «régimen nocturno copulativo o amoroso». De hecho, el cine de Sirk contiene varios símbolos de este régimen, en especial, símbolos cíclicos, como el árbol y la cruz (Durand, 2005: 291).

En cuanto al espejo, es la clave para entender el pensamiento trascendentalista de Sirk. Los espejos están presentes en prácticamente todas las películas mencionadas en este artículo y, muy en especial, en Imitación a la vida (minutos 45, 49-50, 77, 84, 96, 102). ${ }^{16}$ Así mismo, Tiempo de amar, tiempo de morir se cierra con el rostro del protagonista muerto reflejado en el agua. El propio director ha señalado el significado de este simbolizante: «El espejo es imitación de la vida. Lo interesante de un espejo es que no te muestra tal como eres; te muestra tu propio contrario» (Halliday, 2002: 64).

Podríamos decir que el círculo y el espejo expresan de forma simbólica y resumen el contenido trascendentalista del cine de Sirk, entendiendo por tal la necesidad de reflexión interior, de búsqueda de sí mismo, que ha de emprender el hombre. El propio director certifica que éste es el sentido autorial de su cine con las siguientes palabras: «Todo el mundo va detrás de algo, pero al alcanzarlo tampoco es feliz, porque la única escapatoria posible está dentro de ti mismo, hacia ti mismo, si estas huyendo de ti, regresa a ti mismo e intenta amarte tal y como eres en vez de ser otro» (Drove, 1994: 301). Y en otra entrevista insiste en lo mismo a propósito de Imitación a la vida: «La imitación de la vida no es la vida real. La vida de Lana Turner es una imitación muy barata. La chica elige la imitación de la vida en lugar de

${ }^{16}$ El otro gran símbolo de este filme es el diamante (minutos 0, 10, 47, 56, 69, 99, 119). El diamante está asociado con la perfección y la pureza (por eso la protagonista lleva joyas con esta piedra), pero también es una piedra maldita que trae todo tipo de males, pues embruja a quien la lleva. 
ser una negra. La película es una obra de crítica social, tanto de los blancos como de los negros. No puedes escapar de lo que eres» (Halliday, 2002: 179). Igualmente, en Himno de Batalla, la maestra le dice a Hess: «Cada uno es quien es. Los arbustos de las moras no pueden dar la misma sombra que el pino.» Precisamente, el hecho de que mucha gente trate vivir otras vidas, en lugar de ser ellas mismas, produce lo que Thoreau llamaba «una vida de tranquila desesperación» ${ }^{17}$, expresión que resume la carga dramática sobre la que pivota el cine más personal de Douglas Sirk.

\section{REFERENCIAS BIBLIOGRÁFICAS}

EMERson, R. W. (1951). Ensayos escogidos. Madrid: Espasa-Calpe.

Drove, A. (1994). Tiempo de vivir, tiempo de revivir. Conversaciones con Douglas Sirk. Murcia: Filmoteca Regional de Murcia.

DURAND, G. (2005). Las estructuras antropológicas de lo imaginario. Madrid: FCE.

Gomery, D. (1991). Hollywood: el sistema de estudios. Madrid: Verdoux.

HallidAy, J. (2002). Douglas Sirk por Douglas Sirk. Barcelona: Paidós.

GonZÁlez ReQuena, J. (1986). La metáfora del espejo. Madrid: Instituto de Cine y Radiotelevisión.

Thoureau, H. D. (1985). Desobediencia civil y otros escritos. Madrid: Zero.

- (2002). Diarios (breve antología). Palma de Mallorca: Olañeta.

- (2005). Walden. Madrid: Cátedra.

${ }^{17}$ En Sólo el cielo lo sabe, Ronald Kirby dice: «Una inmensa mayoría de mortales vive en desesperación callada. ¿Por qué hemos de afanarnos tanto por alcanzar el éxito? Si un ser no vibra al compás de sus semejantes, quizás es porque oye una música diferente. Debe seguir el ritmo que oiga no importa cuál sea o de dónde venga» (minuto 27). 